\title{
Renewable Energy Investment in Thailand and Vietnam from a Legal Perspective
}

\author{
Piti Eiamchamroonlarp \\ Director of the LL.M. (International) Program \\ Faculty of Law, Chulalongkorn University \\ Bangkok, Thailand \\ piti.e@chula.ac.th
}

\begin{abstract}
Investments are expected to significantly contribute to the growth of the renewable energy industries in Thailand and Vietnam. From the business and financial perspectives, a solid legal framework appears essential for the investors. On the one hand, it should serve as a legal basis addressing how the investor can obtain the right to operate and sell electricity, thus ensuring financial viability of the project. On the other hand, it should serve as a legal protection against risks associated with energy investment, including political risk such as expropriation and Change in Law. This paper finds that legal frameworks governing renewable energy investment in Thailand and Vietnam - an enterprise relying on a licensing system, a single-buyer model, and a power purchase agreement (PPA), are functionally comparable.
\end{abstract}

Keywords-renewable investment, power purchase agreement (PPA), and project finance

\section{INTRODUCTION}

Being parties to the global legal effort to mitigate climate change impacts - the Paris Agreement, Thailand and Vietnam have adopted their energy policy emphasizing role of renewable resources including but not limited to solar, wind, and hydro power as an alternative means to ensure energy security of the country, especially when it comes to production of electricity [1]. Renewable energy investment, whether in Thailand or Vietnam, requires substantial amounts of upfront capital for state-of-the-art renewable technologies and construction work. In overcoming this challenge, the Thai and the Vietnamese government decided to partly liberalize their energy industry by allowing and attracting private investors to participate in the energy industry, especially electricity generation. However, critical questions arise as to address how the investor can obtain rights to invest and operate their renewable energy project and whether the granted rights are sufficiently protected from the perspective of the sponsor and/or lender of the project.

\section{REGULATORY FRAMEWROK FOR RENEWABLE INVEST MENT}

Given the importance of the availability of electricity at a reasonable price - energy security, the electricity industry comprising generation, transmission, and distribution is typically regulated by the state. In many countries including
Thailand and Vietnam, in addition to regulation, the state established state-owned enterprises directly participate in the electricity industry. However, the aforesaid state intervention approach does not mean that private participation is prohibited. Despite establishing state-owned electricity enterprises, Thailand and Vietnam have also adopted a licensing system to grant a person or corporate entity the right to conduct electricity generating activities.

\section{A. Licensing System in Thailand}

Prior to 2007, the Thai legal system had not adopted a piece of legislation serving a systematic legal basis for electricity licensing. Despite some private power producers being present since 1992, the key operators of the Thai electricity industry included state-owned enterprises namely, Electricity General Authority of Thailand (EGAT), Metropolitan Electricity Authority (MEA), and Provincial Electricity Authority (PEA). Laws establishing and empowering independent state agencies with the capacity to grant electricity licenses were absent.

The most recent regulatory reformation of the Thai electricity industry took place in 2007 through the enactment of the Energy Industry Act B.E. 2550 (2007). This law established the electricity licensing system. Under this legal framework those who desire to generate, transmit, or sell electricity are required to obtain an electricity license from the Energy Regulation Co mmission [2]. Put differently, the ERC is vested with the authority to regulate the electricity industry.

As a consequence of the promulgation of the Energy Industry Act (2007), state-owned enterprises like EGAT, MEA, and PEA are no longer the only "key operators" who can produce and sell electricity in Thailand. From an academic point of view, the regulatory reformation enacting the Energy Industry Act (2007) has contributed to the liberalization of the electricity sector in Thailand.

\section{B. Licensing system in Vietnam}

Functionally similar to the Thai Energy Industry Act (2007), Vietnamese Electricity Law was promulgated in 2004 to serve as a legal basis of electricity industry regulation. Electricity activities including activities of organizations or individuals in the domains of electricity development planning, investment, electricity generation, electricity transmission, 
electricity distribution, electric system regulation, electricity market transaction admin istration, electricity wholesaling and retailing, specialized electricity consulting and other relevant activities are subject to the licensing system [3]. This means that an investor desiring to conduct electricity activities in Vietnam is required to obtain applicable licenses from the Vietnamese authorities such as the Industry Ministry for licensing of electricity-generation [4].

Comparable to the electricity industries liberalization journey in Thailand, the Vietnamese Electricity Law (2004) has contributed to liberalization of the electricity industry in Vietnam. The Vietnamese Electric Corporation (EVN), a one member limited liability Company owned by the state with responsibilities to conduct electricity activit ies [5], is no longer the only key electricity operator in Vietnam since private investors are able to obtain electricity licenses in accordance with the Vietnamese Electricity Law (2004).

Taking the Thai Energy Industry Act (2007) and the Vietnamese Electricity Law (2004) into account, investors desiring to invest in and operate a renewable energy project in Thailand and Vietnam can rely on the licensing regime under the laws to obtain the legal right to implement their business plan. However, it shall be noted that, in practice, obtaining the required electricity licenses is not the first step of renewable energy investment in Thailand and Vietnam.

In reality, a project developer typically commences by analyzing the feasibility of a project, formulating a construction plan, and, importantly, carefully determining profitability and financial viability of the project before applying for electricity licenses. Put differently, regardless of readiness of the regulatory regime, the project developer will not proceed without having a certain level of confidence that the renewable project in question will be profitable. A question then arises as to examine how to determine profitability of the project.

Under the current structure of the electricity market in Thailand and Vietnam, a key legal arrangement determining profitability of a power generation project is a long-term power purchase agreement or commonly referred to as "PPA" which shall be discussed in turn.

\section{POWER PURCHASE AGREEMENT (PPA)}

From the outset of a renewable energy project, an investor (or by context a developer) is required to make sure that the produced electricity will be purchased at a reasonable price. In order to answer the aforesaid question, the investor is required to examine the structure of the generation market. Put differently, who will be the purchaser?

\section{A. A single-buyer model: the state as the key customer}

The (wholesale) electricity market in Thailand and Vietnam can be categorized as a single-buyer model. The single-buyer model in this context implies a market in which private electricity producers are required to sell the produced electricity to a single entity which is typically a state-owned enterprise. In Thailand, private producers typically sell electricity to EGAT; whereas, in Vietnam, ENV is responsible for purchasing electricity.

The single buyer model reveals that electricity licenses are not the only legal requirement necessary for project implementation, but also a power purchase agreement as illustrated in Diagram 1 below:

DIAGRAM I. ELECTRICITY GENERATION MARKET IN THAILAND AND VIETNAM (THE SINGLE-BUYER MODEL)

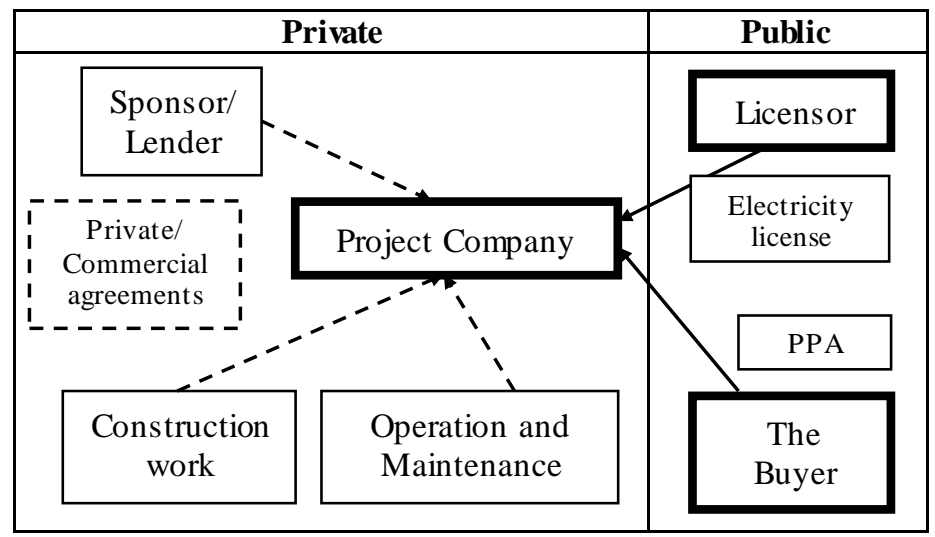

Diagram I exhibits that a project company (typically a special purpose vehicle or SPV) may enter into several commercial agreements with different parties. In order to obtain upfront capital, it may enter into a loan agreement with a financial institution. It may hire a construction company or a company specialized in power plant maintenance. On the other hand, it is required to obtain relevant electricity licenses to legally conduct electricity activities and enter into a power purchase agreement to secure the revenue of the project.

\section{B. Clauses determining financial viability of a renewable energy project in Thailand and Vietnam}

A power purchase agreement or commonly referred to as PPA is an off-take contract, ensuring a minimum amount of project income to cover all or part of the capital investment [6]. From the buyer/off-taker side - EGAT and EVN, a PPA provides the host country with a reliable increase in its available power generation capacity. Standard PPAs for renewable energy projects for example, a standard form of a PPA for a solar project in Thailand or Vietnam contain clauses that perform comparable functions .

From the beginning of an agreement, both the Thai and Vietnamese PPA make clear that the purchaser is a state-owned enterprise: EGAT for Thailand, and EVN or its authorized subsidiaries in Vietnam [7]. Reflecting an essence of a reciprocal agreement, the Seller commits to deliver and sell electricity to the Purchaser [8].

In relation to remuneration and profitability of the project, both Thai and Vietnamese PPAs for a solar project contain a clause concerning a selling tariff. Sub-section 4.3 and Annex I of the Thai Model expressly refer to a feed-in tariff rate (FiT) at THB 5.66 for a purchasing unit; whereas Article 2 paragraph 2 a) of the Vietnamese Standard PPA refers to the Decision (of the Prime Minister) as following: 
a) The Electricity Purchaser shall be responsible for purchasing the entire electricity generated from grid-connected solar power projects with a purchasing tariff at the point of delivery (excluding VAT) as regulated in Clause 1 Article 12 of Decision 11 (emphasis added)

Article 12 of Decision 11 (Prime Minister's Decision on Support mechanisms for the Development of Solar Power Projects in Vietnam No: 11/2017/QD-TTg) states Feed-in tariff (FiT) for grid-connected solar projects as following:

\section{Grid-connected Projects}

a. The Electricity Buyer shall buy all electricity production generated from the Grid connected Projects at a FiT of VND 2.086/kWh (USDcents 9.35/kWh, exclusive of VAT) at the Electricity Delivery Points according to an exchange rate of VND 22,316/USD announced on 10/04/2017 by the State Bank of Vietnam. The FiT shall be subject to fluctuations in the VNDUSD exchange rate. This tariff shall be applied only for the Grid-connected Projects with a solar cell efficiency of more than $16 \%$ or with module efficiency of over $15 \%$.

b. The adjustment of FIT subject to fluctuations in the VND-USD exchange rate shall be executed according to SPPAs issued by the MoIT.

The comparison between the Thai and Vietnamese PPAs for solar projects reveal that both the Thai and the Vietnamese governments have relied on a "Feed-in Tariff or FiT" to guarantee the price of electricity sold by solar resources. In other words, income and profits of a solar project in Thailand or Vietnam rely heavily on these guaranteed selling tariffs.

\section{ANALYSIS ON POLITCAL RISKS}

In practice, a developer desiring to invest and operate a renewable project in Thailand and Vietnam will carefully examine the rate of selling tariffs, and precisely FiT, before making an investment decision as it will determine financial viability of the project. This issue is not only vital for the project developer, but also for the project sponsor or lender as they need to carefully determine bankability of the project in the case the developer desires to use project financing as a funding method.

Project finance has been a popular means of funding energy projects and other infrastructure development projects which require heavy upfront capital. Unlike corporate finance, project finance is based on debt repayment from project company revenues and not on the sponsor or the developer's balance sheet assets [9]. This means that for a renewable energy project relying on project finance, the ability of the project company to sell generated electricity at a favorable price is one of the most important factors for granting the loan. Put differently, how much the project company can sell its electricity to the purchaser at, such as EGAT or EVN, is essential to a decision to grant a loan. This means that sales tariffs are central to the bankability of a project.

For the case of the Vietnamese standard PPA for solar projects, it can be seen that the rate of FiT is subject to the Prime Minister's Decision. This literally means that if the Prime Minister of Vietnam decided to adjust the rate of FiT, for example reducing the rate of FiT from USDcents $9.35 / \mathrm{kWh}$ to USDcents $8 / \mathrm{kWh}$, this adjustment will detrimentally affect the economic viability of a project. A similar challenge applies the Model Thai PPA for solar projects. For example, if the Thai government, relying on its sovereign power, decided to cease its financial support for renewable projects.

The abovementioned challenges - Prime Minister's Decisions and cessation of financial support - can be categorized as "political risk", which is a situation arising from actions by the host government (whether or not arbitrarily or discriminatory) that have a negative impact on the financial or commercial viability of a project [10].

In responding to this kind of challenge, a PPA usually contains a clause that is capable of mitigating or minimizing negative impact of political risk for example, a change-in-law clause, stabilization or economic equilibriu m clause, or a force majeure clause.

Clause 13.1 of the Model Thai PPA for solar projects defines "Force Majeure" as

[A]ny circumstance which uncontrollably took place or may take place and is not caused by a fault or negligence of the Party suffering from the circumstance ... The aforesaid definition shall also mean any act of the government including change in energy policy and change-in-law which makes one Party unable to perform its obligations under the Agreement...

If a suffering party has already informed another party without delay, together with providing detail of the circumstance and a timeframe for remedying damage caused by the circumstance, it shall be released from liability such as failure to perform.

The aforesaid force majeure clause can theoretically be invoked against the Thai government's actions, such as a change in FiT policy. However, a challenge has remained how the force majeure clause would be practically interpreted to act as a legal safeguard against an action of the government.

In the case of dispute, Clause 14.1 of the Model Thai PPA for solar projects requires the Seller to file a claim with the ERC. A decision rendered by the ERC shall be binding upon the Parties and deemed final. If the ERC is unable to make a decision, it shall refer the case to the Thai Court.

However, unlike a force majeure clause of the Thai Model PPA for solar projects, the Vietnamese Standardized PPA for solar projects does not extend its scope to an action of the government such as a change in energy policy or a change in law as following: 
"Force majeure events are any unforeseeable and objective event, which is nonremediable despite all necessary measures and available resources. Force majeure events include:

a) Natural disasters, fires, explosions, floods, tsunamis, epidemics or earthquakes;

b) Violence, riots, war, resistance, sabotage, embargo, siege, blockade, any act of war or community hostilities whether war is declared or not;"

This could mean that if there is a change in the Prime Minister's Decision on Support mechanisms for the Development of Solar Power Projects in Vietnam No: 11 /2017/QD-TTg, an investor may not be able to rely on a force majeure clause to release itself from potential liability such as failure to perform its obligation under the PPA.

\section{CONCLUSION}

Both Thai and Vietnamese governments can rely on their electricity licensing system established under the Energy Industry Act (2007) and Electricity Law (2004) respectively to partly liberalize the electricity (generation) industry and attract private investors to invest and develop renewable energy projects in their countries, thus striking a fair balance between energy security and the need to mitigate climate change challenges.

This paper, however, finds that only the electricity licensing systems appears insufficient to ensure renewable energy investment in Thailand and Vietnam since profitability of the project is also central to the issue. In both countries, PPA, an off-taker agreement, plays vital roles in determining bankability of the project especially when the project relies on project finance as a financing means.

In practice, the developer and potential lender(s) will carefully find legal safeguards against all risks associated with the project including an action of the government such as a change in energy policy on financial support. Taking this practice into account, if the Thai and the Vietnamese governments desire to stimulate renewable energy investment, they should consider implementing legal safeguards against potential risks including an action of the government itself.

\section{REFERENCES}

[1] Thailand Power Development Plan (2015-2036), June 30, 2015 and Prime Minister, Approval of the Revised National Power Development Master Plan for the 201 1-2020 (No.: 428/QD-TTg), 18th March 2016.

[2] The Thai Energy Industry Act B.E. 2550 (2007), Section 47.

[3] The Vietnamese Electricity Law (2004), Artice 3 and 32.

[4] The Vietnamese Electricity Law (2004), Article 8.

[5] Decision No. 562-TTg dated October 10, 1994 of the Prime Minister by on the establishment of the Vietnam Electric Corporation, Article 1 and Decree No. 205/2013/ND-CP dated December 06, 2013, on charter of organization and operation of Viet nam Electricity, Article 3.

[6] Hendrik M. Inadomi, Independent Power Projects in Developing Countries: Legal Investment Protection and Consequences for Development, The Netherlands: Kluwer Law International, 2010, p.45.

[7] Thai Model Power Purchase Agreement for SPP (solar project), Clause 2.1 and Vietnamese Circular Regulating Power Project Development and Standardized Power Purchase Agreement for Solar Power Projects (2017), Article 3.

[8] Thai Model Power Purchase Agreement for SPP (solar project), Clause 4.2, Clause Vietnamese Standard Power Purchase Agreement for Grid Connected Solar Power Project (2017), Clause2.1

[9] John E. Triantis, Project Finance for Business Development, Hoboken Wiley, 2018,p.7.

[10] John Dewar, International Project Finance: Law and Practice, New York Oxford Press 2011, p.94. 